\title{
Federal Government Ethics: Social Media
}

\author{
Darrell Bratton, Capella University, USA
}

Val Candy, Capella University, USA

\begin{abstract}
The federal government has not escaped the increasing worldwide use of social networking. Federal employees are using social networks (social media) for personal and professional reasons and leadership and management are wrestling with the ethical implications. The role of ethical theory and practice in the global business environment is discoursed from the federal government's vantage point with respect to social networking. Given the history of federal government officials and employees acting in an unethical manner, multiple normative ethical theories are investigated. The leadership is examined with a utilitarian lens and non-management employees are studied from the Kantian perspective. Additionally, virtue ethics are discussed as a counter argument to the aforementioned theories. Cultural intelligence is discussed as having reciprocal relationship with the multicultural and global aspect of social networking. It is argued that ethical intelligence needs to be created to support the minimum requirement of a code of ethics for federal employees to follow when using social networking.
\end{abstract}

Keywords: Social Network; Federal; Utilitarian; Kantian; Ethical Intelligence

\section{INTRODUCTION}

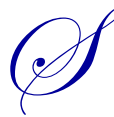

ocial media encompass technologies that facilitate social interaction, collaboration and decision-making, marketing and branding across and between stakeholders. These technologies include blogs, wikis, media (audio, photo, video, text) sharing tools, networking platforms (such as Facebook), and virtual worlds (Bryer \& Zavattaro, 2011). The federal government can be thought of as a business with a public trust whose leaders are elected to serve the people. As such, they apply utilitarian principles in the collection and reallocation of public resources to benefit the largest number of people possible - or for the greater good (Mitchell, 1999).

The United States Federal government's use of social media is facing a critical ethical challenge that has global implications since the U.S. is widely considered to be a leading role model for other nations to follow. This means that U.S. leadership and practices influence a far-reaching multicultural and multigenerational workforce rooted in Kantian ethical philosophy. Ethical challenges with global implications are not new to the federal government and neither are questionable or unethical behaviors associated with leadership figures and followers. Notably, the scandal of the Regan Administration saw more than a hundred officials charged with legal or ethical wrongdoings. Similarly, the Clinton Administration attracted numerous allegations of dubious ethical allegations throughout the term in office (Mitchell, 1999). More recently, the Secret Service scandal of 2012 drew international negative attention in Latin America when the public's trust and value system was violated by serving officials charged with protecting President Obama. Thompson (2010) found that not only are moral issues complex and based on human judgment, but that the number of stakeholders are enormous because of globalization and social networking.

The use of social media by the government came out of a failed attempt to create a more efficient information technology infrastructure, similar to the private sector. Part of the problem was that the government used proprietary systems when smaller more agile systems existed that shared services like social media does (Kundra, 2010). Moreover, the U.S. Chief Information Officer's 25-point plan to restructure the management of information technology ensures that the use of social media will continue to grow internally and, therefore, so will the ethical challenges (Kundra, 2010). Hasson (2012, para. 1) reported that the government's social media guru, Justin Herman, helped draft the Digital Government Strategy (GSA, 2012) which states that developing and increasing the use of social media is important because the public has the expectation that the government will be accessible at any time of the day or night through any digital device that the person owns (para. 2). 


\section{ETHICAL INVENTORY}

Ethical theory is a key component in the practice of the government's business. The Ethics Research Center (2011) reported that its survey indicated a historically low number of incidents of wrongdoing in the American workplace and an increase in reports of wrongdoing; however, there was also increased retaliation against whistleblowers. Also, weak ethical cultures in organizations increased to 42 percent from 35 percent a couple of years ago (p.12). Two external factors that influenced the results were the economy and the use of social media. These two factors were found to influence people's ethical behavior at home and at work (p.6). The implication is that those using social media have a higher acceptance rate of questionable activities than colleagues that are not using social media (p.14).

Given the current fiscal crisis within the federal government, the practical business dominant culture promoted by its leaders (agency leaders and management) is to get more done for less. Bryer and Zavattaro (2011) contend that both scholars and practitioners are visibly excited as they contemplate the potential power of social media to enhance "government transparency, public participation, and intergovernmental and cross-sector collaboration" (p. 325). However, the insecurity about job stability and the decrease in salaries may contribute to government employees engaging in unethical conduct. According to the Ethics Research Center (2011), there is also an increase in the percentage of employees who feel pressure to reduce their ethical standards in order to maintain their positions (p.12).

To combat past unethical incidents and potential future misconduct, the Executive and Judicial branches have mechanisms in place to counteract undesirable conduct. The Executive Branch has the "U.S. Office of Government Ethics" (OEG) whose mission it is to nurture good ethical standards and increase the public's confidence in the fairness and honesty of how the government operates (United States Office of Government Ethics, Mission \& Responsibilities, n.d. para. 1). The judicial branch has a code of conduct for Judges and non-judges (staff). The code of conduct for judges has five canons that are there to instill public trust in the judicial branch and state that judges should be dignified, avoid any indication of impropriety, be diligent, fair and impartial, cannot engage in political activity, but may participate in external activities that are congruent with the office (Administrative Office of the U.S. Courts, Judicial Code of Conduct for United States Judges, n.d., p.1). For the staff of the judicial branch, the same five cannons apply, but they are not as stringent as for judges (Administrative Office of the U.S. Courts, Code of Conduct for Judicial Employees, n.d., p.1).

There is no direct mention of ethical social media behavior in the "Standards of Ethical Conduct for Employees of the Executive Branch" (United States Office of Government Ethics, 2011), although the U.S. Office of Special Council does address the permissible uses of social media in regard to the Hatch Act that restricts political activity of executive branch employees. The U.S. Office of Special Council (2012) is open to employees using social media in semi-political activities as long as the political statements are directed toward all social media friends or followers (p.3-4). In contrast, the judicial branch does have a specific document about the ethical use of social media. According to the Administrative Office of the U.S. Courts (2010), the use of social media, within the judiciary, has had a positive impact with respect to recruiting, training employees, as well as gathering and disseminating information. Along with the benefits, there are ethical concerns related to security and privacy of the court's and private employee information (p. 5). For example, employees are reminded to take extra care not to inadvertently comment on a pending case via social media. Specifically, when employees are using social media, they should be vigilant to maintain confidentiality, not lend the prestige of the office, not do or say anything that would embarrass the court, not display deference with respect to access to court, and avoid political activities (p. 7).

\section{UTILITARIAN VERSUS KANTANIAN THEORY AND RIGHTS}

From the management perspective, the utilitarian theory is dominant as the goal is to have the benefits outweigh the harms; but from the non-management employee viewpoint, the Kantian rights to free choice are dominant. Given these competing underlying philosophies, the potential for conflict between organization and individual goals seems inevitable when making social media accessible in the workplace. 
Dennis (2001) asserted that the increased use of social media has led to employee productivity problems as employees were found to be shopping on auction websites, reading the news, and engaged in online gaming and chatting on social media sites (p.380). This increase in the unethical use by employees has led to employers using tools that traverse the lifecycle of the relationship with the employee, from pre-hiring to termination (p.381). Although the employer has the legal right to monitor, or even restrict, the online activities of employees, there are some instances the employee has the right to use social media; for example, when it is concerned with the advancement of mutual goals of a group of employees, such as communication about salaries, working hours, or conditions (p.384). This puts the employer in a precarious position because an increase in the use of social media to escalate the transfer of knowledge amongst employees also increases organizational exposure to liability issues as an extension of privacy issues. Ethical violation in the absence of legal liability is also present when employees post the organization's trademarked information or share defamatory comments (p. 383).

\section{Risks}

Social media postings can also create problems for the employer when the public takes exception to the lifestyle of federal employees. Indeed, McDonald Dryburgh, (2010) noted that the private lives of government employees can come back to haunt them when they place their personal information on social media sites. The activities in which a federal employee is engaged outside of work, such as being unfaithful to a spouse or drug use, can be found on social media sites and reported to employers (p. 39). Consequently, the offending employee may be terminated if that individual holds a sensitive position requiring security clearance. Notably, President Obama's first term of office administration requested that every prospective employee disclose any form of social media activity that might embarrass the president (McDonald Dryburgh, 2010, p.8). Dennis (2011) argues that employees who are terminated for inappropriate use of social media would enjoy minimal legal protection. Even though these terminated employees could seek refuge in the First Amendment or argue for a violation of the Stored Communications Act, a significant majority of federal, and other, employees are employed "At-Will", which means that the employment relationship can be terminated without cause (p. 386). Alternatively, Weiss (2011) reported that there are cases when employees have been sued for maintaining company clients as social media contacts. In such cases, the organization terminated the employee for fear of theft of client lists (p. 20).

Furthermore, Light and McGrath (2010) discussed the design of the popular social media application Facebook and found that the designers followed the same consequentialist perspective as government management (p.292). However, by following this philosophy, there are inherent ethical problems that could lead to users inadvertently committing ethical violations (p.305). Specifically, the default settings in Facebook are open and, over time, Facebook has moved the security button off the first page to a deeper level of the application (p.302). This makes it harder for users to set the necessary security settings to protect their preferred privacy (p. 305).

Also, with the anonymity built into Facebook, others can post photos and names of others without the true identity of the account holder known. Facebook does not check the information of those creating accounts; hence, a public profile of an individual could be created with conversations and photos posted without that individual ever knowing (p. 306). The ethical implication for an organization is that an unflattering depiction of an organizational representative could be posted while attracting inevitable adverse reactions. Although the diffusion of responsibility for security is an ethical issue for social media sites, the repercussions are vast.

\section{Recruitment Benefits}

Even with the complex ethical and legal challenges that employers face, Dennis (2011) admitted that employers realize that the benefits of social media outweigh the consequences and are finding it to be a great marketing apparatus (p.382). Calogero (2011) supported this finding and reported that the federal government is using social media to recruit a younger acquisition workforce. Almost half of the current acquisition workforce is at least 50 years old and the field is understaffed. In response to the workforce crisis, the Office of Management and Budget (OMB, 2009, p. 807) promulgated the "Acquisition Workforce Development Strategic Plan" which moved the government toward more modern recruiting techniques. Government agencies can create profile pages and use video links or other social media applications, like Twitter, to contact a large number of applicants for almost no cost at all. Also, this creates an image that the job is for younger applicants, which is an indirect method, but also 
they use a direct method by placing ads on professional social media sites, like Linked In (p. 824), which is having the effect of diminishing the usefulness of the traditional federal job advertising website of "USAjobs.org" (p. 807). Another social networking site is Second Life. In this virtual world, a user creates an avatar. An avatar is person or animal, or combination of the two. The person can then interact with other avatars and go to an "Island" - that is a piece of land owned by a person or organization. Many federal agencies interact in this virtual world and the intelligence community held a job fair in a similar environment.

\section{ETHICAL THEORIES AND PRACTICAL BUSINESS DECISIONS}

Light and McGrath (2010) argue that there are a number of normative ethical theories that seek a best method of governance of human behavior from a moral standpoint (p.291). Ünal, Warren, and Chen (2012) claim that normative theories can be categorized as deontological, teleological, and virtue but that they are not mutually exclusive (p. 9). Tobin (2011) compared and contrasted Kantian and utilitarian ethics and noted that deontological reasoning is based on universality of the decision, and that utilitarians are like scholar researchers who are impartial observers (p. 599)

When compared, both private and public sector employees were found to prefer the Kantian approach to ethics rather than the consequentialist form of moral reasoning (Wheeler \& Brady, 1998, para. 51). Additionally, differences between the two have been compared for many years and may be the most important contrasting theories in the ethics discipline. Other ethical theories, such as virtue ethics, over the past ten years, have been promoted as an alternative to the aforementioned theories; however, their distinctions still dominate the discourse (Wheeler \& Brady, 1998, para. 1). In a review of the literature, Wheeler and Brady (1998) found that managers were consequentialist and suspected that government employees were deontological due to the rules and regulations they have to follow and the directive to show impartiality and justice (para. 3). Wheeler and Brady (1998) argue that by understanding the differences, there may be better communication between the two groups (para. 4).

\section{Utilitarian Theory}

Postema (2006) explained that public utility is the basic moral philosophy of "[Jeremy] Bentham" (p.109) and, moreover, that Bentham insisted that the job of government is the betterment of the "universal interest" (p. 110), which the management in government is trying to do with social media. While the goal is to achieve the utmost happiness for the community, or stakeholders, this may not be possible, and the government must make the decision to sacrifice the happiness of some to bring the utility to the highest number of citizens (p.113). Thompson (2012) further explained that utilitarianism, as developed by John Stewart Mill and Jeremy Bentham, can be thought of as an optimization equation that is so general in maximizing benefit and minimizing harm that trade-offs are hard to determine (p. 629). This is in line with analysts who have studied gambling, with the common solution being to "reflect both benefit and harm as quantities of worth or value that include the probability that the beneficial or harmful outcomes will actually materialize" (p. 629). Bentham (1996) discussed the principle of utility and noted that it either approves or disapproves of every choice in accordance with whether it adds or reduces the happiness of the entity that has an interest in the outcome. Ünal et al. (2012) reported that Bentham took care to delineate that one person was not given more weight than another person and the decisions can be economically based by using cost benefit analysis (p. 11). The leadership in government is wrestling with how to handle the risks of social media from a utilitarian perspective and Thompson (2012) claims the meta-ethics of risk are loosely connected to agency and with agency comes responsibility (p. 636).

\section{Kantian Theory}

Wheeler and Brady (1998) submitted that deontological thinking dates back before Immanuel Kant, who is credited with articulating the modern theory in the seminal works "Foundations of the Metaphysic of Morals (1785) and Critique of Practical Reason (1788)" (para.3). Thompson (2012) noted that the Kantian theory decides on the right action based on the categorical imperative that the rule followed could become a universal edict (p.629). Additionally, Dion (2010) added that a characteristic of this philosophy is a low degree of relativism which translates to choosing the moral deed because it will benefit everyone concerned, most of the time (p.244). Furthermore, it has been suggested by some that the overarching theme of this theory is to encourage the standard of 
fairness in decision-making, but others have suggested that it is as simple as treating others as you would have them treat you (Thompson, 2012, p. 630). Wheeler and Brady (1998) connected this theory to government employees and related that the public sector values of property, equality, and freedom are particularly deontological and must be preserved for everyone (para. 11), which means that when government employees are faced with ethical dilemmas, they choose solutions that are aligned with principles or regulations, with less of a concern for the consequentialist goal of overall efficiency and what is best for greatest number in the community (para.51). Lastly, Light and McGrath (2010) asserted that where social media is concerned, the Kantian person is an autonomous agent who makes rational moral decisions, which implies that the impact of technology and the ethics involved can be addressed (p. 291).

\section{Theories Across Functional Areas}

The two theories come together as the organizational leadership is concerned with the overall welfare of the stakeholders and the employees are concerned with justice, rights, and rules. Ünal et al. (2012) found that if supervisors are not grounded in the normative theory of utilitarianism, unethical supervision can occur. For example, if a manager fighting for limited resources makes choices that benefit that manager's department or agency to the detriment of overall organizational benefit or efficiency, then unethical supervision has occurred (p.11). This can also include violating the subordinate's Kantian rights of dignity, privacy, property, autonomy, and safety (p.13). It is incumbent on the leadership to model utilitarian ethical behavior and dissuade unethical behavior in supervisors so that the Kantian rights of employees are preserved (p. 16).

\section{LABOR PROCESS THEORY}

Government employees are Kantian, in part, due to the "Labor Process Theory (LPT)" (Ackroyd, 2009, p. 263 ) and this could also have an influence on the unethical use of social media. LPT was conceived by Karl Marx at the turn of the 19th century but did not have widespread use until the 1974 publication of Harry Braverman's book "Labor and Monopoly Capital" (Ackroyd, 2009, p. 264). Braverman advanced the idea that work, as a labor process, increased value and capital for the organization. When employees contract out their labor to the employer, they are obedient to the instructions of the employer and the skills of employees are altered in the pursuit of superior organizational performance (Ackroyd, 2009, p. 264).

According to Thompson and Smith (2009), since the 1980s LPT has become a dominant method in the workplace in the U.S., Britain, and other developed countries. In the U.S., the "deskilling" of employees has been key to reforming the workplace. This deskilling exists in the federal workforce where one person does a specific task and is only allowed by the employer to gain skills in that task. This can lead to boredom and possible time wasting on social media sites. Thompson and Smith (2009) further explained that in the 1990's there was a movement to upskill workers to handle the advancements in computer technology but that the workers resisted it and managers were reluctant to give up the control (p. 255).

It may seem that social media reduces productivity as Dennis (2001, p. 380) pointed out, which is counter to the LPT; however, Powell (2012) argued that social media increases productivity by harnessing the power of team collaboration (p. 12). The future of social media will transform organizations by adding the gaming mechanics of scoring to non-game activities and thereby create a rewards-based atmosphere to work processes (p.7-8). The "Social Learning Boot Camp" (p.7) was developed to train corporate leadership in new social media technologies and how to attract and retain the most talented employees (p. 7). The paradigm shift to a game-based organization has already begun with executives having an Amazon-type rating next to their name, which is already occurring on few websites, and future employees looking at the rating to decide if they want to work for that organization (p. 9). The practical example of a utilitarian increase in productivity, based on a game, is "Foldit" (p.12) where players of a collaborative online video game found the solution to a molecular puzzle that scientists had been working on for 15 years. The discovery was the deciphering of protein that allowed HIV and other viruses to multiply (p.12). So, while it may seem that workers are being unproductive with social media at work, there are some significant advances in science being made as well. Future leaders will not only have to understand how to harness social media for utilitarian purposes, but they will have to incorporate stakeholder theory with the employee being one of the major stakeholders. Freeman (1994) argued that blending of the concepts of business and ethics together will yield a 
stakeholder concept that is more informative and granular than the general ethics concepts (p.409-410). Powell (2012) supported this and noted that in future workplaces, Millennials will expect the same technology at work that they have grown up with at home, as well as in school, and that mobile technology will be ubiquitous (p. 10).

The private sector is ahead of the public sector in learning about how to manage the Millennials. Education is the key for federal leadership from an ethical and technological standpoint. Camarena (2011) contended that over the past decade, the government has spent hundreds of billions of dollars on information technology (IT) and has not seen the efficiencies realized by the private sector. The reason is that government managers do not see the government as a business and do not recognize that IT is used to support the business processes but to enhance services (p. 28). In order to achieve the benefits going forward, there should be three distinct areas of technological education - the non-IT workforce, the IT professionals, and the government leadership (p. 28).

IT professionals should focus on sharing knowledge amongst each other and across functional areas. Acquisition employees, who are being recruited, should have IT experience to better interpret the requirements of IT department in purchasing applications and systems. Another area for improvement is recognizing and leveraging emerging technologies which include social networking tools. Lastly, IT professionals have to understand the tradeoff between security for infrastructure and the needs of the business side of the organization, again crossing functional areas (Camarena, 2011, p. 29). The federal government's IT departments have historically stayed with legacy systems long past their end of life because of the difficulty transitioning the non-IT users to new systems and transferring the data to new technologies. This raises ethical issues surrounding data security and utilitarianism. Harris, Lang, Yates, and Kruck (2011) expressed the need for ethics to be included in IT education because the internet is omnipresent and data from social media sites, emails, and web traffic are being tracked and logged by government computers, as well as private information is being stored in electronic healthcare databases. Students see how easy it is to gather data without having any moral foundation for how that information should be used or protected (p. 184). Furthermore, the common use of social media and mobile devices has created behavioral standards amongst students which was shown in the political uprising that spread across the Middle East in 2011, known as the "Arab Spring". The curriculum should cover normative ethical theories as they relate to subjects such as database design and maintaining the privacy rights of users (p.285).

Changing the culture of the non-IT users can be done through changing the culture of the government leadership. To become a government leader, it is required that the person be savvy in the areas of human resources, finances, and information technology, so it is important that leaders be change agents when it comes to adopting new technologies. One way to achieve this is by teaching them how IT functions within their organization and to have them make IT a part of the strategic initiatives to make the organization more efficient (Camarena, 2011, p. $32)$.

\section{DIVERSE AND MULTICULTURAL PERSPECTIVES}

Vallor (2010) argued that virtue ethics should be applied to social media on the basis that it is better suited than teleological and deontological frameworks (p. 157). Virtue ethics are able to be systematically applied and are not restricted by cultural values. Also, virtue ethics works well with the reciprocal communication that takes place in social networking so that the moral outcome is determined communally, which resolves ontological conflicts with constructivist and phenomenologist (p.158). Directly contrasting with the deontological approach, virtue ethics considers the contextual nature of the dilemma and requires that the decision-maker be cognizant as the context evolves (p.159), which makes this philosophy relevant because of the speed of technological changes in social media. Strictly utilitarian or deontological approaches, without the sensitivity to context, make them less than optimum choices. Virtue ethics has its detractors as well, who question the embeddedness of culture when ethical issues arise that go beyond culture (p.159). Moreover, critics of virtue ethics argue that normative evaluations of technology, which affect numerous diverse cultures but are based in a particular culture, cannot be effective; however, this presupposes that the framework is stagnant and requires universal consensus. The common misconception is that normative approaches cannot be systematic unless they are static outside of the boundaries of the debate and that they are mutually exclusive (p.161). 
Light and McGrath (2012) supported Vallor (2010) and noted that Foucault's ethical philosophy supports contextually dependent moral conduct by actors who are part of a network of processes, institutions, and technologies where their roles are in flux. By adopting this perspective, insight is obtained about the virtue ethics of the users of social networks, like Facebook, as they may log in as a learner, professor, spouse, or sibling (p.306). Conversely, Postema (2006) countered Vallor (2010) and noted that Bentham learned from Hume that the fundamentals of virtue are positioned in utility (p.109) and Bentham (1996) wrote that when someone argues against the principle of utility, they are not saying that it is wrong but that it is being applied incorrectly in a given circumstance (p.16).

\section{MULTICULTURAL EFFECTS OF SOCIAL NETWORKING: CULTURAL INTELLIGENCE}

Facebook is touted as the most popular social networking site with an estimated 750 million users as of 2011 (Qui, Lin, \& Leung, 2012, p. 108). Prior research has documented the cultural differences between Asian (Chinese) and Western (American) cultures, but this cultural difference of collectivism for Asians is also present in the social networking application used in China "Renren", as users of both applications felt that Facebook was more individualistic. Also, as users switched between applications, their behavior changed to match the cultural aspect of site, suggesting that users will easily change their behavior based on the shared practices of the online culture in which they are participating. Furthermore, the shared norms of the online application indicate that shared ethical values can be obtained through the multicultural emersion. Lastly, the social networking environment allows users to experience multiple cultures, simultaneously, thereby increasing the user's cultural intelligence (Qui et al., 2012, p. 116).

Cultural intelligence is critical in the globalized world of social networks that bring cultures together in unexpected ways. Stein (2012) reported that pictures went viral on Israeli social networks in 2011 when the abducted soldier, Gilad Shalit, was released after being held for five years in a prisoner exchange for over 1,000 Palestinians. Criticism of the Prime Minister happened on the social network because the prisoner swap was seen as a political ploy because it happened so close to the election. Moreover, the social network is used by people on both sides of the border, between Israel and Palestine as well as the anti-occupation supporters. From the perspective of the Arab Spring, this digital trend is changing the future of multicultural relations in the region (p.893)

\section{RECOMMENDATIONS AND GUIDELINES FOR GOVERNMENT LEADERSHIP}

Developing guidelines for the responsible use of social networking in the workplace is a multifaceted endeavor. The guidelines need to include the normative foundations for management and employees. It also has to cover the legal aspect so as to protect the organization while still protecting the rights of the employees. As mentioned above, social networking can be very positive in terms of collaboration, creativity, and increasing cultural intelligence. With the speed of technological change, there is no way to predict the future; however, one thing is certain - that social networking will continue to grow and the world's citizens will continue to learn from each other through shared norms and absent political ideologies. The following recommendations and guidelines will create a framework for leadership and the current and next generation of employees.

According to Wickham and O'Donohue (2012), while a code of ethics is the standard practice and an alluring option because it is very visible and economical to create, it is not enough (p. 10). Organizations need to create and support "ethical intelligence" (EI) at the individual and organizational level as this goes deeper than just having a code of ethics copied from a legal boilerplate (p.9). EI, within the individual, starts with "ethical maturity" (EM) (p. 12). EM can also be also moral intelligence, and it is combined with emotional intelligence, social intelligence, and cognitive intelligence to create the ethically intelligent individual. Emotional intelligence is concerned with intrapersonal abilities and emotional balance, social intelligence is concerned with interpersonal abilities and being able to adhere to social norms, moral intelligence is concerned with being able to autonomously make decisions on common ethical principles, and cognitive intelligence is concerned with being able to filter information in a rational way that make it useful (p.12). When employees possess these, the organization expects a utilitarian outcome of the decisions made (p.14-15). For the organization to have EI, it must create an ethical infrastructure and promote an ethical culture across all functional areas and then constantly reinforce the ethical standards of the organization. By constantly reminding employees of good and bad ethical choices that the 
organization has made, it keeps the pockets of unethical employees to a minimum. The three keys to creating the infrastructure are: 1) have ethics permeate the organization through connecting the practices with the processes in every functional area, 2) recruit ethically intelligent employees and reward employees publically and privately through performance reviews for making ethical decisions, and 3) create an ethical climate which has formal policies and informal cultural norms such as encouraging social responsibility (p. 15 ).

As for the leadership from which the employees will ultimately obtain the organizational cultural messages, there are seven characteristics that need to be in place. They need to: 1) have a vision, 2) have principles, 3) be open to stakeholders' views, 4) motivate subordinates by modeling ethical behavior, 5) be accountable, 6) challenge processes, and 7) be supportive of ethical development. By integrating these components, an organization can create a competitive advantage in a socially responsible way (Wickham \& O'Donohue, 2012, p.22). An additional recommendation is to hire an executive in charge of ethics, which many companies are doing. The person should be well versed in both business ethics and information technology ethics so that cross-functional training, at all levels of the organization, can occur (Harris et al., 2011, p.185).

Lastly, the Ethics Resource Center (2011) supported Wickham and O'Donohue (2012) and suggested that based on the current trends, executives should invest heavily in ethics and elevate the importance of ethics by ensuring that employees are aware that there are funds available for training and rewarding ethical behavior. Encourage Human Resources to make ethical leadership a part of management's performance evaluations. Social networks can be to improve the ethical culture by having online discussions about ethical issues. Finally, update the policy against retaliation for whistleblowers and make the policy known so that potential whistleblowers will feel safer (p. 51-51).

\section{Guidelines}

According to the Administrative Office of the U.S. Courts (2010), the following guidelines should be implemented for judicial employees with respect to social networking, and since this guide does not yet exist for the executive branch, only the non-judicial branch specific guidelines will be discussed.

Federal government managers should limit the scope of the restrictions on social media use, given the particular security in IT infrastructure requirements of the agency. For example, with a limited amount of bandwidth, video streaming and Peer to Peer sharing should be prohibited. Professional listings on social networking sights should be allowed as long as the specific department and, in some cases for security reasons, the agency is not mentioned. Due to the wide range of applications available and new ones being created all the time, it should be up to the individual to know which applications they use and how those applications affect the bandwidth of the Internet pipe. One way to accomplish this is to let everyone know that their Internet traffic usage can be monitored and, if there is a problem, they will be contacted. This will assist in keeping applications with high traffic usage to a minimum.

Additionally, the guidelines should be written with following trends toward future employee expectations in mind. Powell (2012) reported that the following trends would be clearly visible by the year 2020: 1) The workplace is expected to have more of a multicultural and multi-generational workforce, 2) the economy will shift from one based on services to one based on knowledge, 3) globalization will increase the speed in which organizations have to adapt to new technology, 4) information will be more and more digital so that information security will be critical, 5) mobile technology will be omnipresent and employees will want their personal devices to connect to the work network, 6) social media deployment will be expanding within organizations, 7) co-creation of value between the public and government will increase, 8) social learning will replace brick and mortar type pedagogies, 9) socially and ethically responsible organizations will have a competitive advantage, and 10) people who have little aversion to technology, Millennial, will be the future leadership (p.10).

\section{CONCLUSION}

The public sector has a long history of ethics violations. Given the rise of social media and new ethical challenges it brings, a rethinking of ethics policies and practices is required. Social media is a global way of doing 
business and a means by which the government can become more efficient. With government leaders viewing the use and exploitation of social media from a different normative theory than government employees, there is potential for incongruence. This can be overcome as leadership is trained on the multicultural and multigenerational aspects of social media. As cultural intelligence is increased, the government leaders and managers will be better able to address social media governance. The employees, on the other hand, will have to learn ethical intelligence to mitigate unethical conduct and increase productivity. The recommendations and guidelines offered are a framework for building an ethical organization with the sensitivity of current trends. These policies toward ethics and social networks will stand the test of time, given globalization and the changing demographic of the workforce.

\section{AUTHOR INFORMATION}

Darrell Bratton is a doctoral learner specializing in organization and management. He has worked extensively in IT within a federal setting and holds a Chief Information Officer certification from the Federal CIO Council and University of Maryland University Council (UMUC). He earned a Masters degree in Technology Management Information Systems \& Services, and an MBA graduating from the University of Maryland University College (UMUC) in Adelphi Maryland. E-mail: Darrell.brattonsr@ gmail.com (Corresponding author)

Val Candy is a doctoral learner of management with Capella University focusing in marketing and organizational performance. She earned her BS and MS with Hodges University. She has worked extensively in leadership positions and upper management both in the United Kingdom and in the United States within the public and private sector. She is published in the areas of leadership, strategic planning, and business economics research. E-mail: vucandyms@gmail.com

\section{REFERENCES}

1. Ackroyd, S. (2009). Labor process theory as 'normal science'. Employee Responsibilities and Rights Journal, 21(3), 263-272.

2. Administrative Office of the U.S. Courts. (2010). Resource packet for developing guidelines on use of social media by judicial employees. Retrieved December 8, 2012, from http://www.uscourts.gov/uscourts/RulesAndPolicies/conduct/SocialMediaLayout.pdf

3. Administrative Office of the U.S. Courts. (n.d). Judicial code of conduct for United States Judges. Retrieved December 8, 2012, from http://www.uscourts.gov/Viewer.aspx?doc=/uscourts/RulesAndPolicies/conduct/Vol02A-Ch02.pdf

4. Administrative Office of the U.S. Courts. (n.d.). Code of conduct for judicial employees. Retrieved December 8, 2012, from http://www.uscourts.gov/Viewer.aspx?doc=/uscourts/RulesAndPolicies/conduct/Vol02A-Ch03.pdf

5. Bentham, J. (1996). An introduction to the principles of morals and legislation (Collected Works of Jeremy Bentham). Clarendon Press. Retrieved December 4, 2012, from http://socserv2.socsci.mcmaster.ca/ econ/ugcm/3113/bentham/morals.pdf

6. Bryer, T. A., \& Zavattaro, S. M. (2011). Social media and public administration: Theoretical dimensions and introduction to the symposium. Administrative Theory \& Praxis, 33(3), 325-340.

7. Calogero, K. (2011). Become a fan of government procurement on Facebook: How the federal government's acquisition workforce can use social networking websites to recruit new employees. Public Contract Law Journal, 40(3), 807-828.

8. Camarena, S. (2011). Educating the Federal Government. IEEE Computer Society, 13(6), 28 - 33.

9. Dennis, C. M. (2011). Legal implications of employee social media use. Massachusetts Law Review, 93(4), $380-395$.

10. Dion, M. (2010). Corruption and ethical relativism: What is at stake? Journal of Financial Crime, 17(2), 240-250.

11. Ethics Resource Center. (2011). National business ethics survey. Retrieved November 14, 2012, from http://www.ethics.org/nbes/files/FinalNBES-web.pdf

12. Freeman, R. (1994). The politics of stakeholder theory: Some future directions. Business Ethics Quarterly, 4(4), 409-421. 
13. GSA (2012) Digital government strategy—agency milestones. Retrieved December 8, 2012, http://www.howto.gov/digital-strategy/digital-government-strategy-agency-milestones

14. Harris, A. L., Lang, M., Yates, D., \& Kruck, S. E. (2011). Incorporating ethics and social responsibility in IS education. Journal of Information Systems Education, 22(3), 183-189.

15. Hasson, J. (2012), Feds@Work: Government's Social Media Guru. Retrieved December 8, 2012, from http://gov.aol.com/2012/08/14/feds-work-governments-social-media-guru/

16. Kundra, V. (2010). 25 Point implementation plan to reform federal information technology management: The White House. Retrieved December 8, 2012, from http://www.dhs.gov/sites/default/files/publications/digital-strategy/25-point-implementation-plan-toreform-federal-it.pdf

17. Light, B., \& McGrath, K. (2010). Ethics and social networking sites: A disclosive analysis of Facebook. Information Technology \& People, 23(4), 290-311.

18. McDonald Dryburgh, M. (2010). Public virtue, cyber-vice: Rethinking public service ethics in the age of the internet. (Doctoral dissertation). ProQuest Dissertations and Theses, 168. Retrieved from http://search.proquest.com/docview/740105818? accountid=27965 • (740105818).

19. Mitchell, C.E. (1999). Violating the public trust: The ethical and moral obligations of government officials. Public Personnel Management, 28(1), 27-38.

20. Postema, G. J. (2006). Interests, universal and particular: Bentham's utilitarian theory of value. Utilitas, 18(2), 109-133.

21. Powell, T. (2012). Unleashing the power of social media to improve employee productivity. CPA Practice Management Forum, 8(7), 7-12.

22. Qui, L., Lin, H., \& Leung, A.K. -y. (2012). Cultural differences and switching of in-group sharing behavior between an American (Facebook) and a Chinese (Renren) social networking site. Journal of Cross-Cultural Psychology, 44(1), 106-121.

23. Stein, R. L. (2012). StateTube: Anthropological reflections on social media and the Israeli State [Abstract]. Anthropological Quarterly, 85(3), 893-916.

24. Thompson, L. (2010). The global moral compass for business leaders. Journal of Business Ethics, 93(suppl. 1), 15-32.

25. Thompson, P. B. (2012). Ethics and Risk Communication. Science Communication, 34(5), 618-641.

26. Thompson, P., \& Smith, C. (2009). Waving, not drowning: Explaining and exploring the resilience of labor process theory. Employee Responsibilities and Rights Journal, 21(3), 253-262.

27. Tobin, T. (2011). The Relevance of Trust for Moral Justification. Social Theory \& Practice, 37(4), 599628.

28. U.S. Office of Special Council. (2012). Frequently asked questions regarding social media and the Hatch Act. Retrieved December 8, 2012, from http://www.osc.gov/documents/hatchact/federal/Social\%20Media\%20and\%20the\%20Hatch\%20Act\%2020 12.pdf

29. Ünal, A. F., Warren, D. E., \& Chen, C. C. (2012). The normative foundations of unethical supervision in organizations. Journal of Business Ethics, 107(1), 5-19.

30. United States Office of Government Ethics. (2011). Standards of ethical conduct for employees of the Executive Branch. Retrieved December 4, 2012, from http://www.oge.gov/Laws-andRegulations/Employee-Standards-of-Conduct/Standards-of-Ethical-Conduct-for-Employees-of-theExecutive-Branch-(PDF)/

31. United States Office of Government Ethics. (n.d) Mission \& responsibilities. Retrieved December 8, 2012, from http://www.oge.gov/About/Mission-and-Responsibilities/Mission---Responsibilities/

32. Vallor, S. (2010). Social networking technology and the virtues. Ethics and Information Technology, 12(2), 157-170.

33. Weil, N. (2009). How to...harness the power of social networking. CIO, 22(9)

34. Weiss, M. (2011). The use of social media sites data by business organizations in their relationship with employees. Journal of Internet Law, 15(2), 16-27.

35. Wheeler, G. F., \& Brady, F. (1998). Do public-sector and private-sector personnel have different ethical dispositions? A study of.. Journal of Public Administration Research \& Theory, 8(1), 93.

36. Wickham, M., \& O'Donohue, W. (2012). Developing an ethical organization: Exploring the role of ethical intelligence. Organization Development Journal, 30(2), 9-29. 